of after-shocks; all these features pointing to a complicated origin covering a large area.

(5) Burma, divided into three main structural units-the Shan plateau (A, Fig. 2), consisting of rocks of Mesozoic and older ages, the Tertiary basin of the Irrawaddy valley (B), and the range of the Arakan Yoma of late Mesozoic and early Tertiary times (C). They are separated by zones of faulting, with which many of the epicentres of Burmese earthquakes are associated, especially those of the destructive earthquakes of 1839 and 1858, the former near Mandalay and the latter near Thayetmyo and Prome. During the years 1929-31, there was a remarkable series of eight earthquakes, the epicentres of which, numbered in the order of occurrence in Fig. 2, are marked by a linear arrangement close to the eastern fault.

Most of the Indian earthquakes of the last forty years have been investigated by officers of the Geological Survey of India, yet it must be admitted that the state of seismological research in the country is behind that in some other lands. In Japan there are a hundred and five seismological observatories, in the United States forty-two, but in India only six, and not one official devoted entirely to seismological subjects. Mr. West suggests that the work done more or less independently by the Geological Survey, the Meteorological Department and the Survey of India should be co-ordinated and expanded by founding what would practically be an Earthquake Research Institute with its headquarters, say, at Shillong, provided with many now instruments for stations new and old, and with officers who, after a great earthquake, should at once proceed to the central area and establish round it a network of temporary stations in order to determine the epicentres and focal depths of the after-shocks. C. D.

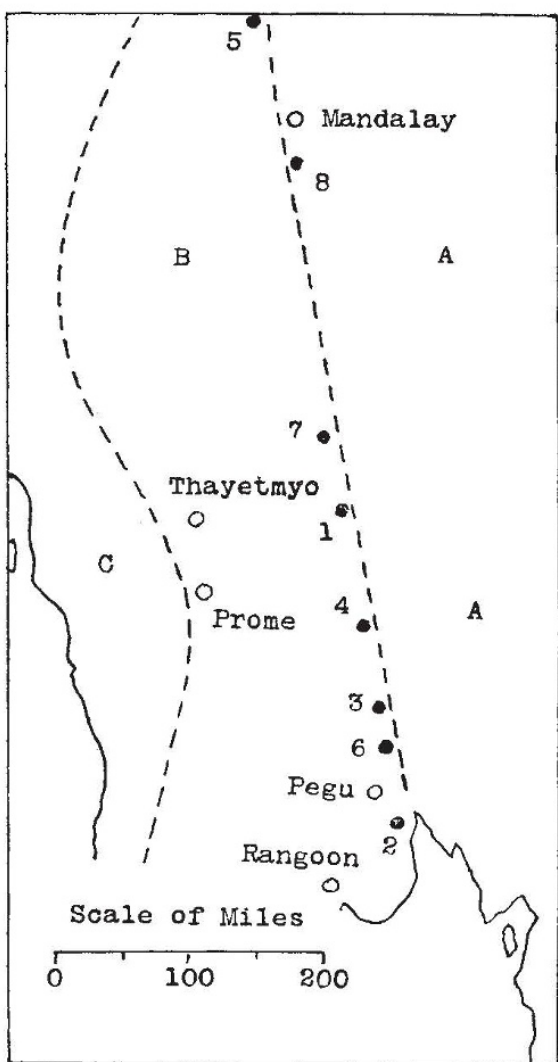

Fig. 2.

Distribution OF EaRthQUakes IN BuRMa.

\title{
Incidence and Causes of Stammering
}

$S^{\mathrm{T}}$ TAMMERING is one of those abnormalities sufferers from which fall between two stools. It is scarcely the concern of the family doctor, and yet is outside the scope of ordinary educational methods. Of recent years, psychological treatment has helped many individuals to cope with speech disabilities, but it commonly happens that more time and expense are called for in the achievement of a cure on these lines than stammerers are able to give, and so for one reason or another it usually falls to the lot of the individual stammerer to cure himself.

It is with special reference to some interesting figures supplied by the Stammerers' Club of New South Wales* that this short commentary on an important subject is given; as the result of questionnaires sent out to the members this Club has elicited most interesting information.

Whilst in most instances of stammering there is actual physical disability of some kind, nevertheless, for the most part the trouble is to be found in a constitutional nervousness or sense of inferiority. From the statistics from New South Wales, it is noteworthy that although serious illness is actually

* Stammering : its Canse and Cure. (The Handbook of the Stam merers' Club of New South Wales.) Pp. 72 . (Sydney : Stammerers" Club of N.S.W., n.d.). credited with nine per cent in the list of causes, no definite physical disease is said to have any serious influence. The cause of stammering generally is attributed to such psychological causes as shock, imitation, fright and being bullied or laughed at. In all these, it is evident that individual nerve sensitiveness or feeling of inferiority is the chief underlying trouble. That this nerve weakness is often inborn seems to be emphasized by the fact that in no less that fifty-one per cent of the instances dealt with the stammerer began before the age of five years, and no less than ninety-three per cent experienced the onset before the age of ten. Granted that unfortu nate conditions in upbringing produced such psychological disturbance as to impair capacity for normal speech, it certainly cannot be held that all these stammerers were born with strong nerves or the capacity for developing sound defences against the stresses of life.

As regards position in family, it does not seem to matter whether one is born early or late if one is to experience the disadvantage of stammering; it is true that there is the difference between thirty-eight per cent as regards 'elder' children and twenty-five per cent as to 'youngest', but as the 'intermediate' 
members are put down as thirty-seven per cent there is really not much in it. In regard to reaction to school conditions this is said to have been 'good' in eighty-one per cent and in nineteen per cent 'bad', whereas it might well have been expected to be the other way round.

A further point of interest which comes out of these statistics of the N.S.W. Stammerers' Club is that seventy-six per cent stammerers were boys and twenty-four per cent girls; moreover, the serious influence of this disability in the case of the latter as regards life as a whole is suggested by the figures which tell us that at thirty years of age approximately seventy-three per cent of the boys had got married whilst only thirty-seven per cent of the girls had been equally successful.

Usually relief of stammering depends on the determination of the individual sufferer who will make use of certain rules of elocution and self-help such as are readily accessible from teachers and handbooks on the subject. Certainly the stammerer who sets out to cure his difficulty must attain three objects ; namely, (1) confidence ; (2) attainment of a new habit; (3) the maintenance of a restful state of mind and body. He must learn to relax. He must learn to use a new voice with a timing slightly but definitely different from that which he habitually uses when stammering. He can look forward confidently, if he determines to practice and to rely on himself; in any case he can perhaps take some comfort from remembering that he is one of a com. pany of very famous men. Amongst kings one may remember that Louis II and Louis XIII of France are said to have stammered badly. Whilst at least one Queen of England (Mary II) was also troubled in the same way. I have always understood that Charles Lamb abandoned an intended career in the Church because of his speech disability, although stammering has not always been incompatible with a reputation as a famous speaker. Charles Kingsley, Phillips Brooks and Father Hugh Benson, all distinguished in the pulpit, are said to have stammered at times.

\section{E. L. HOPEWELL-ASH}

\title{
South-Eastern Union of Scientific Societies
}

\author{
Annual Congress at Hastings
}

\begin{abstract}
$\mathrm{T}$ HE forty-second Congress of the South-Eastern Union of Scientific Societies was held at Hastings on June 8-12. The Mayor of Hastings, Alderman A. Blackman, welcomed a large gathering of representatives of affiliated societies and other members of the Union at the opening ceremony on June 8, when Prof. F. E. Weiss was installed as president of the Union for the ensuing year, and delivered his presidential address on "Competition and Co-operation in Nature".

In the past, competition in commerce and industry was regarded as beneficial to the community, but competition among industrialists is no longer in such great favour, and oven in agriculture efforts are being made to restrict it. On the other hand, co-operation, which is the basis of communal organization, is not generally called in question. Prof. Weiss pointed out that these forces also exist in Nature. Darwin had pointed out that, owing to the enormous reproductive capacity of most plants and animals, a weeding out process is inevitable; there is a struggle for existence under which only the fit survive. Many plants produce hundreds of thousands of seeds, but do not appreciably increase in numbers on an area already covered with vegetation. In the case of plants, the struggle for light is often the dominant factor. There is also competition for the necessary food among animals, and the larger and stronger animals have an advantage over the smaller and weaker ones. In the case of carnivorous animals, however, the race is not always to the strong, but also largely to the swift and agile. Though the dictum "Nature red in tooth and claw" causes some people to regard evolution as a continuous competitive warfare in which might is always triumphant, Darwin pointed out that there are certain instinctive characters in many animals which make for the preservation of the race as a
\end{abstract}

whole and as apart from the individuals, and that probably in these the basis of our moral nature had its beginnings. Parental instincts play a very important part in the survival of the more highly developed animals; there is here no competition for food between parents and offspring, but, on the contrary, parents will often starve themselves for the benefit of their young. Prof. Weiss then dealt with numerous cases of symbiosis, the classical example in plants being found in lichens. He took two ex amples to illustrate competition and co-operation among plants, the rosette-forming plants of grass lands illustrating competition, and plants of the Leguminoseæ with their nodules carrying nitrifying bacteria exemplifying co-operation.

"Our Changing Flora" was the theme of an address delivered by Dr. R. W. Butcher to the Botanical Section of the Union. Man has brought about remarkable changes in the flora of Great Britain. The draining of fens, the turning of heathland into forest, rivulets made into canals, the digging of railway cuttings and making embankments have all played an important part in bringing about changes. There never has been, and probably never will be, anything static about the flora. The ecologist recognizes a continual change of vegetation as a basic principle in plant succession. Captain Diver has directed attention to rapid topographical changes in the South Haven peninsula of Dorset since 1700 . Large masses of lsoetes echinospora are now found on the bed of Littlesea, yet this plant was unknown there a few years ago. Pearsall has recorded many changes in the vegetation of the English Lakes, these changes being in accord with changes in the nature of the lake bottoms.

Mr. L. F. Salzman gave a paper on "The Writing of Local History" to members of the Archæological 